\title{
Небезпечні ситуації при виконанні лапароскопічної герніопластики
}

\author{
O. O. VOROVSKYI
}

Regional Hospital for disabled of World War II, Vinnytsia

\section{DANGEROUS SITUATION WHEN PERFORMING LAPAROSCOPIC HERNIOPLASTY}

\begin{abstract}
Проаналізовано причини інтраопераційних ускладнень у 234 хворих, яким було виконано лапароскопічну герніопластику 3 приводу гриж різної локалізації, які мали місце у 7-ми (2,9 \%) випадках на початку освоєння методики: пошкодження нижньої епігастральної артерії - 2, позаочеревинне пошкодження сечового міхура 1 , кровотеча 3 дрібних судин сім'яного канатика - 1, пошкодження сліпої кишки - 1, кишкова непрохідність - у 2-х випадках. Основними причинами їх виникнення є порушення правил введення інструментів та основних вимог підготовки паціснтів до лапароскопічних операцій, при дотриманні яких можна їх уникнути.
\end{abstract}

There were analyzed the causes of intraoperative complications in 234 patients who underwent laparoscopic hernia hernioplasty with different localization, which occurred in 7 (2.9\%) cases in the early development methodologies: damage lower epigastric artery -2 and extra-abdominal damage of the bladder - 1, bleeding from small vessels of the spermatic cord - 1, damage cecum - 1, ileus - in 2 cases. The main reasons for their occurrence is a violation of input tools and basic requirements for training patients to laparoscopic surgery, under which they can be avoided.

Постановка проблеми і аналіз останніх досліджень та публікацій. Вважають, що грижі живота - одне із найбільш розповсюджених захворювань серед населення земної кулі, яке зустрічається до $6 \%$ населення, тобто 50 випадків на 10000 осіб [6]. Відповідно, герніопластика $€$ найбільш розповсюдженою операцією, так, за рік дане оперативне втручання в США виконується більше 700 000, в Росії-200 000, у Франції-110 000, у Великобританії - 80 000, оскільки тільки даним способом можна усунути даний дефект черевної стінки [5]. Частота грижосічення в стаціонарах України складає до 25 \% від усіх оперативних втручань, є другою за розповсюдженістю в світі [4].

Аутопластичні методи не завжди дозволяють усунути обширний грижовий дефект, зважаючи на нестачу власних тканин і нерідко через високий ризик розвитку респіраторно-циркуляторних розладів у ранньому післяопераційному періоді внаслідок підвищення внутрішньочеревного тиску [7].

Після застосування “ненатяжних" способів із застосуванням синтетичних матеріалів на поліпропіленовій основі відзначають зниження рецидивів залежно від локалізації та походження від 3 до 30 \% [3].

Проте дані операції залишаються травматичними, необхідність широкої лапаротомії, тривалі терміни госпіталізації і тривалий період реабілітації дають можливість припускати, що відсоток рецидивів значно вищий, ніж дають автори публікацій, i, крім цього, мають значно вищий відсоток специфічних ускладнень (нориці, сероми, крайовий некроз рани тощо) [2].

Лапароскопічна хірургія відкрила нові можливості в лікуванні хворих із грижами. Розроблено методику внутрішньочеревної фіксації імплантата за допомогою лапароскопічних інструментів, для якої не характерні ранові ускладнення, скоротилися терміни післяопераційного перебування хворих у стаціонарі [8].

Проте при застосуванні даних методів відзначають збільшення таких небезпечніших ускладнень, як пошкодження судин, нервів, кишки, сечового міхура тощо, які складають, за даними різних авторів, від 2,5 до 5,0 \% [4].

Пошкодження судин передньої черевної стінки належать до одного з найбільш частих ускладнень цієї групи і складають, за даними літератури, від 0,14 до 2,5 \%. Найбільші технічні складнощі виникали при ушкодженні епігастральних судин. Пошкодження великих заочеревинних судин є найтяжчим ускладненням лапароскопії, що призводить до летального результату, за даними різних джерел, у $10-56 \%$ випадків, а частота їх виникнення коливається від 0,03 до 0,4 \%. Нерідко ушкодження судин поєднуються з газовою емболією [1]. 
Пошкодження внутрішніх органів на етапі діагностичних і лікувальних маніпуляцій - ускладнення, що також нерідко виникає при лапароскопії. Як правило, воно пов'язане з використанням високочастотних електрокоагуляторів (в основному монополярних) або при надмірному прагненні хірурга закінчити операцію лапароскопічно при вираженому злуковому процесі чи при неуважності хірурга та недостатньому його досвіді. Як найбільш серйозне ускладнення операції виділяємо пошкодження кишкової стінки. У деяких випадках частина сліпої або сигмоподібної кишки розташовується заочеревинно, що має місце при ковзних грижах. Імовірність ушкодження кишки існує при розтині очеревини і виділенні грижового мішка. Особливо небезпечні коагуляційні пошкодження, які можуть проявитися через три і більше діб [1].

Матеріали і методи. 32004 року до сьогодні в умовах хірургічного відділення обласного госпіталю для інвалідів Вітчизняної війни накопичений досвід лапароскопічної герніопластики складає 234 випадки. Із них при пахвинно-стегновій локалізації - $132(56,4 \%)$, при пупковій - 66 (28,2 \%), де в 24 $(10,3 \%)$ як симультанна операція при лапароскопічній холецистектомії; білої лінії живота - 24 (10,3 \%); спігелієвої лінії - 4 (1,7 \%); правої здухвинної ділянки $-2(0,9 \%)$. Хворих із рецидивними грижами було 28 (12,0\%) осіб, де $22(9,4 \%)-3$ пахвинною локалізацією, 6 (2,6 \%) - 3 пупковою. Післяопераційні грижі мали місце у 16 (6,8\%) пацієнтів, де $6(2,6 \%)$ випадків $з$ пупковою локалізацією, 6 (2,6 \%) - в правому підребер'ї внаслідок виконання міні-лапаротомій при тяжких формах холециститу, 2 (0,9 \%) - білої лінії живота, 2 (0,9 \%)правої здухвинної ділянки. Вік хворих коливався від 19 до 76 років, середній склав $(64 \pm 2,3)$ року. Таким чином, на вибір застосування лапароскопічного методу лікування даної патології найменше впливав вік хворого, більшої уваги надавали індексу маси тіла, наявності супутньої патології, локалізації, розмірам та площі грижового дефекту. Для гриж вентральної локалізації була використана класифікація SWR, розроблена J. Chevrel iA. Rath (1999р.): серединна локалізація (M) - 90 (38,5 \%) пацієнтів, у $6(2,6 \%)$ - в підреберно-боковій ділянці $\left(\mathrm{L}_{1}\right) ;$ у 6 $(2,6 \%)$ - у клубово-боковій ділянці $\left(\mathrm{L}_{3}\right) ; \mathrm{W} 2$ - у 65 $(27,8 \%)$ пацієнтів, W3 - у 37 (15,8\%); R1 - у 18 (7,7 \%) хворих, R2 - у 10 (4,3\%) пацієнтів. Чоловіків було $110(47,0 \%)$, жінок - $124(53,0 \%)$.

Результати досліджень та їх обговорення. У хворих, яким було виконано лапароскопічну герніопластику, ускладнення мали місце у 7-ми (2,9\%) випадках на початку освоєння методики: пошкодження нижньої епігастральної артерії - 2 та позаочеревинне пошкодження сечового міхура -1 , кровотеча 3 дрібних судин сім'яного канатика - 1, пошкодження сліпої кишки - 1 , кишкова непрохідність - у 2-х випадках. В одному випадку кровотечу зупинили за допомогою біполярної коагуляції, в другому випадку - в позаочеревинний простір було встановлено дренаж. Пошкодження нижніх епігастральних судин у всіх випадках відбулося у пацієнтів з ожирінням I-III ступенів. Виражений передчеревний ліпоїдоз робив менш помітними складки черевної стінки, які $є$ важливими анатомічними орієнтирами. На сьогодні відразу після розтину очеревини ми виробляємо іiї тракцію, що викликає розвиток локальної передочеревинної емфіземи. Цей прийом дозволяє відшарувати очеревину від підлеглих тканин, в тому числі й від епігастральних судин. Крім цього, вважаємо обов'язковим проведення ретельного гемостазу навіть при незначній за інтенсивністю й тривалістю кровотечі. Це мало місце в одному випадку, де після проведення десуфляції в кінці операції було діагностовано пошкодження дрібних судин сім'яного канатика, що тривалий час дифузно кровоточать. У даній ситуації здійснювали дренаж через троакарну рану передочеревинного простору і встановлювали його на активну аспірацію до 2-х діб. Крім того, можливі пошкодження зовнішньої клубової, огинаючої гілки глибокої клубової та затульної артерій. Ці ускладнення найбільш серйозні при такій операції. Всі судини в даній ділянці можуть бути кліповані, за винятком зовнішньої клубової артерії, для відновлення якої необхідна конверсія.

В одному випадку мало місце пошкодження сліпої кишки при мезоперитонеальному ії розташуванні при ковзній грижі. Дане ушкодження було діагностовано інтраопераційно, ліквідовано за рахунок ендоскопічного дворядного шва та було виконано дивульсію ануса за Суботіном. В наступних подібних випадках виконували розсічення очеревини в ділянці медіальної складки. Виділення грижового мішка виконували без використання коагуляції.

Кишкову непрохідність у післяопераційному періоді спостерігали у 2-х випадках, де в одному випадку тонка кишка зачепилась за скріпку на очеревині, як за рибальський гачок, в другому - внаслідок адгезії кишки з поліпропіленовою сіткою при ненадійній ії перитонізації.

Гематома пахового каналу і мошонки, парестезії, больовий синдром після операції та невралгій, нагноєння троакарної рани, сероми, рецидиви захворювання виникають, за літературними даними, в $1,52-9,3 \%$ випадків [5, 6, 7, 9, 23, 26], проте, оскіль- 
ки вони не становлять небезпеки для стану хворого, в даній роботі не розглядались.

На момент виконання лапароскопічної герніопластики спайковий процес виявлено у 32 (13,7 \%) хворих. Найбільш часто виявляли зрощення великого сальника і петель тонкої кишки з очеревиною. Наступним етапом операції був адгезіолізис і підготовка зони грижового дефекту до пластики. Розділення спайок між грижовим мішком і прилеглими органами виконували з використанням біполярної електрокоагуляції. Для полегшення поділу зрощень у грижового мішку використовували такий прийом: асистент вільною рукою вправляв грижовий мішок у черевну порожнину. Для уникнення пошкодження внутрішніх органів голкою Вереша відмовились від iii застосування, оскільки, за даними ряду авторів, вони є найбільш небезпечними ускладненнями даного етапу лапароскопії і складають, за даними різних авторів, від 0,14 до 0,7 \% [1]. В даних випадках перший троакар проводили під візуальним контролем.

При своєчасній діагностиці ускладнень показані екстрена лапаротомія, ревізія черевної порожнини та усунення виявлених пошкоджень. Однак, якщо хірург володіє достатнім досвідом, то при невеликому пораненні він може спробувати ліквідувати ускладнення за допомогою лапароскопічної техніки.

На момент виконання лапароскопічної герніопластики спайковий процес виявлено у 34 (87,2%) хворих, у 5 (12,8 \%) пацієнтів констатовано його відсутність. Найбільш часто виявлялися зрощення великого сальника і петель тонкої кишки з очеревиною. При невправимих грижах у 11 (28,2%) пацієнтів у всіх випадках у грижового мішку виявилися фіксовані пасма великого сальника. При рецидивних грижах відзначено зрощення пасом великого сальника з грижовим мішком і передньою черевною стінкою в зоні грижових воріт.

\section{СПИСОК ЛІТЕРАТУРИ}

1. Послеоперационные вентральные грыжи после лапароскопических вмешательств / Э. Г. Абдулаев, В. В. Феденко, В. В. Бабышин, Г. В. Александров [и др.] // Эндоскопическая хирургия. -2001 . - № 4. - С. 25-28.

2. Адамян А. А. Путь герниопластики в герниологии и современные ее возможности / А. А. Адамян // Материалы I Международной конференции “Современные методы герниопластики с применением полимерных имплантатов”. - М., 2003. C. 15 .

3. Егиев В. Н. Современное состояние и перспективы герниологии / В. Н. Егиев // Герниология. - 2006. - № 2. - С. 5-11. 4. Ничитайло М. Ю. Лапароскопическая герниопластика в лечении сложных и рецидивных грыж / М. Ю. Ничитайло, И. И. Булик, А. П. Кондратюк // Клінічна хірургія. - 2006. № 4-5. - C. 45 .
Мобілізація товстої кишки поблизу їі стінки при лапароскопічних операціях із приводу ковзних пахвинних гриж також може привести до розтину просвіту органа. Застосування атравматичних кишкових затискачів, біполярної електрокоагуляції, препарування кишки на видаленні від її стінки і адекватна візуалізація зони оперування є заходами профілактики подібних ускладнень. Пошкодження сечового міхура під час лапароскопічної герніопластики виникають, як правило, внаслідок електротравми при розтині очеревини пахової ділянки або при відновленні ії цілісності за допомогою степлеpa і становлять близько 0,3 \% випадків. Обов'язкова катетеризація сечового міхура перед операцією і контрольована електродисекція дозволяють уникнути даного ускладнення.

Висновки. При виконанні лапароскопічної герніопластики для уникнення ятрогенних ушкоджень порожнистих органів та судин оперуючий хірург повинен мати достатній досвід та володіти ендоскопічним швом. Основними причинами їх виникнення $є$ порушення правил введення інструментів та основних вимог підготовки пацієнтів до лапароскопічних операцій. Найчастіше не встановлюється назогастральний зонд, а при операціях на нижньому поверсі черевної порожнини - сечовий катетер. Використання атравматичних кишкових затискачів, застосування біполярної електрокоагуляції, препарування кишки на видаленні від іï стінки є заходами профілактики вищевказаних ускладнень.

Перспективи подальших досліджень. У перспективі буде продовжено вивчення причин ускладнень при лапароскопічній герніопластиці та удосконалення ендоскопічних маніпуляцій для їх уникнення.

5. Пришвин А. П. Оптимизация методики лапароскопической герниопластики / А. П. Пришвин, Н. А. Майстренко, С. Б. Сингаевский // Вестник хирургии им. Грекова. - 2003. - Т. 162, № 6. - С. 71-74.

6. Седов В. М. Осложнения эндовидеохирургичесой герниопластики / В. М. Седов, В. В. Стрижелецкий, А. Б. Гуслев // Вестник хирургии им. Грекова. - 2003. - Т. 162, № 1. - С. 8081.

7. Тимошин А. Д. Стационарзамещающие технологии в хирургии грыж / А. Д. Тимошин, А. Л. Шестаков, А. В. Юрасов // Герниология. - 2007. - № 3. - С. 8-11.

8. Beldi G. Laparoscopic ventral hernia repair is safe and costeffective / G. Beldi, R. Ipaktchi, M. Wagner// Surg. Endoscopy. -2006 . - Vol. 20. - P. 92-95. 